\title{
Severely repressed lodgepole pine responds to thinning and fertilization: 19-year results
}

\author{
by Craig Farnden ${ }^{1}$ and Les Herring ${ }^{2}$
}

A set of speculative and exploratory treatments was applied to a severely repressed strand of 18-year-old lodgepole pine in 1979. After 19 years, various combinations of row thinning, hand thinning and fertilization have provided a remarkable range of results, with the best treatments gaining $3 \mathrm{~m}$ in top height and $8 \mathrm{~m}$ in apparent site index (reference age 50 years breast height) over the untreated stand. The best results were observed where both growing space and nutrition were improved. Extrapolation of the results using simulation suggests large gains in yield at harvest.

Key words: thinning, fertilization, lodgepole pine, repression, stagnation

Une série de traitements expérimentaux et exploratoires a été appliquée à un peuplement très opprimé de pin lodgepole âgé de 18 ans en 1979. Dix-neuf ans plus tard, diverses combinaisons d'éclaircie en rangée, d'éclaircie manuelle et de fertilisation ont démontré un spectre remarquable de résultats, où les meilleurs traitements ont démontré des gains de $3 \mathrm{~m}$ dans la hauteur des houppiers et de $8 \mathrm{~m}$ dans l'indice apparent de la station ( l'âge de référence étant de 50 ans à hauteur de poitrine) par rapport au peuplement non traité. Les meilleurs résultats ont été observés là où l'espacement et la nutrition ont été tous deux améliorés. L'extrapolation des résultats au moyen d'une simulation laisse entrevoir d'importants gains au niveau du rendement au moment de la récolte.

Mots-clés: éclaircie, fertilisation, pin lodgepole, répression, stagnation

\section{Introduction}

Lodgepole pine (Pinus contorta Dougl. ex Loud.) often regenerates at very high stand densities following wildfire. In many cases, densities (trees per hectare) are so high that height growth is reduced, thereby limiting production of merchantable timber. The earliest recognized cases of this effect were in extremely dense stands (> 200000 trees/ha) where growth reductions were large and distinct. The effect was so obvious that it was referred to as "stagnation," likely based on the assumption that height growth and stand development had all but ceased.

Mitchell and Goudie (1980) and Goudie (1980) identified a trend of increasing growth losses with increasing density, and suggested that in most cases density-related height growth losses were small and not obvious. As a result, they suggested the term "repression" instead of "stagnation." Threshold establishment densities for the onset of repression were first estimated at 50000 trees/ha by Mitchell and Goudie (1980) but were later identified as low as 20000 trees/ha using controlled field (W. Johnstone $^{3}$, personal communication). J.S. Thrower and Assoc. (1993) used retrospective studies to identify repression in 30- to 40year-old stands with densities as low as 10000 trees/ha, however establishment densities would have been much higher.

Theories for the mechanisms of repression not already discounted generally focus on the supply/uptake of water and nutrients, the ability of trees to use those building blocks in photosynthesis, and the allocation of photosynthates to various woody tissues and respiration (Goudie 1980, Mitchell and Goudie 1980, Worrall et al. 1985, Keane and Weetman 1987, Worrall 1995). While various authors have put different emphasis on differ-

${ }^{1}$ Consulting Forester, 3207 Vista View Road, Prince George, British Columbia V2N 6R7. E-mail: craigfarnden@ @elus.net

${ }^{2}$ Forester, BC Ministry of Forests - Prince George Region, $10114^{\text {th }}$ Ave., Prince George, British Columbia V2L 3H9. E-mail: Les.Herring@gems7.gov.bc.ca ${ }^{3}$ Silviculturist, B.C. Ministry of Forests, Kalamalka Research Station

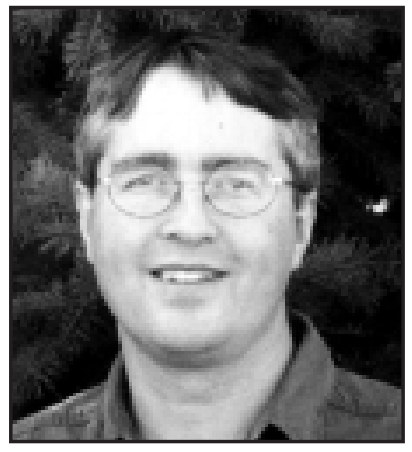

Craig Farnden

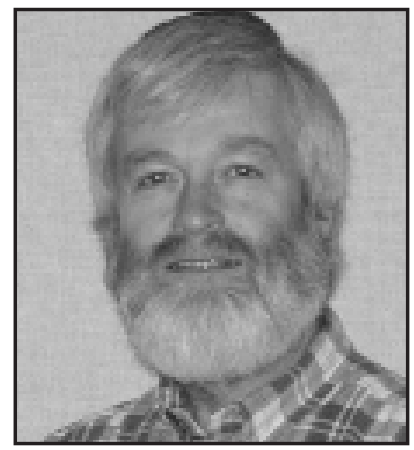

Les Herring ent steps in this process, none have made definitive arguments for any one causal process, and it seems probable that all are inter-related.

On the supply side, there is discussion about the dilution of resources over a large number of individuals, with doubts expressed that sufficient resources are available to provide for base-level needs of such a population. This argument is at least partially supported by the fact that severe repression most commonly occurs on sites with relatively low moisture and nutrient availability. On the transport side, there is discussion about low hydraulic conductivity in the stems of repressed trees, possibly leading to greater levels of moisture stress in the crowns. On the allocation of photosynthates, there is discussion of both excessive respiratory surface area relative to photosynthetic capacity, and of a heavy allocation of photosynthates to root production, which is typically observed on poorer sites. Any or all of these could be causal or contributory factors.

Despite not having a thorough understanding of causal mechanisms, foresters have long recognized the potential timber supply impacts of repression, and have attempted 
Table 1. Climatic summary statistics for the Mossvale moist cool variant of the Sub-Boreal Spruce biogeoclimatic zone. Top values are means, while bracketed values indicate observed ranges)

\begin{tabular}{ccccc}
\hline $\begin{array}{c}\text { Annual } \\
\text { Precipitation } \\
(\mathbf{m m})\end{array}$ & $\begin{array}{c}\text { Growing Season } \\
\text { Precipitation } \\
(\mathbf{m m})\end{array}$ & $\begin{array}{c}\text { Annual } \\
\text { Snowfall } \\
(\mathbf{c m})\end{array}$ & $\begin{array}{c}\text { Annual } \\
\text { Temperature } \\
\left({ }^{\circ} \mathbf{C}\right)\end{array}$ & $\begin{array}{c}\text { Frost } \\
\text { Free Period } \\
(\mathbf{d a y s})\end{array}$ \\
\hline 727.4 & 272.6 & 306.3 & 1.5 & 975 \\
$(628.3-838.2)$ & $(196.8-432.0)$ & $(241.7-355.5)$ & $(-0.2-3.3)$ & $(751-1198)$ \\
\hline
\end{tabular}

Source: Reynolds (1989) as reported in Delong et al. (1993)

many silvicultural remedies. Traditional hand thinning methods were usually rejected as excessively expensive due to the large number of stems to be cut, and various other methods were evaluated. Mechanical implements, such as anchor chains, sharkfin barrels, chopper drums, dozer blades and rotary mowers, were attached to crawler or wheeled tractors to clear swaths through dense young stands (Crossley 1952, Lotan 1967, Bella and DeFranceschi 1977, Forrester 1989, Hedin 1986, Bella 1990). Crossley $(1950,1956)$ also investigated use of the herbicide 2,4-D to thin stands based on desired mortality rates with different herbicide formulations. Schmidt (1987) discussed various options for treating these stands, including thinning, fertilization, and destroying stands to start over.

In the late 1970s, a series of mechanical row thinning trials was initiated in the interior of British Columbia to test low-cost methods of treating large areas of highly dense fire origin lodgepole pine stands. On one such trial near Fish Lake $\left(53^{\circ} 47^{\prime} \mathrm{N}\right.$, $122^{\circ} 17^{\prime} \mathrm{W}$ ), approximately $40 \mathrm{~km}$ southeast of Prince George, British Columbia, a pair of exploratory thinning and fertilization trials was also introduced. The treatments applied were intended to exceed the normal range of operational practices, with the hope of finding new and effective methods of overcoming repression. This paper describes the results and some possible interpretations from these trials.

\section{Site and Stand Conditions}

The site is located on a broad glacial outwash plain with deep coarse textured soils. The soil matrix is primarily sands with up to $35 \%$ silt. Coarse fragments (gravel and cobbles) occupy 10 to $75 \%$ of the soil volume. The mineral soil is covered by a very thin, poorly developed mor humus.

The site fits within the Pine-Feathermoss-Cladina site series of the Mossvale moist cool variant of the Sub-Boreal Spruce biogeoclimatic zone as described by DeLong et al. (1993). This ecosystem unit is typified by a subxeric soil moisture class and very poor soil nutrition. Understory vegetation includes welldeveloped moss and lichen layers, and relatively weak cover of primarily ericaceous shrubs. A climatic summary for the biogeoclimatic subzone is provided in Table 1.

The subject stand of lodgepole pine originated after a 1961 wild fire. Glen (1979) and Herring and Cassar-Torreggiani (1980a, b) described the stand as "pale green and grossly overstocked" with an average density of 122000 trees/ha, and local densities up to 700000 trees/ha. The average height of dominants and codominants ranged from 1.7 to $3.5 \mathrm{~m}$ at 18 years of age, with the largest values closely associated with areas of lower stand density. Nitrogen deficiencies were suspected, and confirmed by subsequent soil and foliage analysis. Foliar nitrogen concentrations were found to be $1.08 \%$, suggesting a growth limiting deficiency.

\section{Experimental Design and Establishment}

The Fish Lake site was originally selected to test biological effects of mechanical row thinning (Glen 1979). A 36.4-ha unit was subdivided into 21 treatment units, 14 of which were row thinned in 1978. Except for the row thinning treatment, the original trial was never established. Subsequently, six of the 21 treatment units were utilized for two smaller multi-factor thinning and fertilization studies (Fig. 1).

One study, hereafter referred to as the row thinning trial (Herring and Cassar-Torreggiani 1980a), was overlaid on mechanically row-thinned treatment units. It included the following treatment combinations with the additional treatments applied in the fall of 1979:

1. Mechanical row thinning

2. Treatment 1 plus selective hand thinning

3. Treatment 1 plus $150 \mathrm{~kg} / \mathrm{ha} \mathrm{N}$

4. Treatment 1 plus selective hand thinning plus $150 \mathrm{~kg} / \mathrm{ha} \mathrm{N}$

Row thinning was done using the Hydro-Axe, an articulated frame, rubber-tired carrier with a front-mounted, single-shaft rotary cutting deck. The machine cut and mulched $2.5-\mathrm{m}$ parallel swaths through the stand, leaving 1- to 2-m residual strips of undamaged trees. Where required, residual strips were thinned selecting the best trees at approximately a spacing of $1 \mathrm{~m} \times 1 \mathrm{~m}$ using brush saws. Prilled, agriculture grade urea fertilizer (46-0-0) was evenly applied as the source of nitrogen using a cyclone seeder (Herring and Cassar-Torreggiani 1980a).

The second trial, hereafter referred to as the fertilizer thinning trial, was also established in the fall of 1979 on three of the unthinned treatment units (Herring and Cassar-Torreggiani 1980b). Treatments included:

5. Broadcast application of $200 \mathrm{~kg} / \mathrm{ha} \mathrm{N}$

6. Broadcast application of $400 \mathrm{~kg} / \mathrm{ha} \mathrm{N}$

7. Concentrated strip application of $400 \mathrm{~kg} / \mathrm{ha} \mathrm{N}$

8. Broadcast application of $800 \mathrm{~kg} / \mathrm{ha} \mathrm{N}$

9. Concentrated strip application of $800 \mathrm{~kg} / \mathrm{ha} \mathrm{N}$

Broadcast fertilizer applications were done using a cyclone seeder. At the two highest application rates, uniformity was ensured by making repeated passes, with direction of travel shifted $90^{\circ}$ on each subsequent pass. Strip applications used the same total quantity of fertilizer as the broadcast applications, but concentrated the fertilizer into narrow strips with the intent of achieving a lethal dose in contact areas. Strip applications were achieved by hand delivery of measured quantities of fertilizer along premarked lines.

Both trials were established as factorial experiments with randomized block designs. In each trial, treatments were randomly assigned to $20 \times 25 \mathrm{~m}, 25 \times 25 \mathrm{~m}$ or $25 \times 30$-m plots in each of three blocks. Due to the a priori application of row thinning, however, randomization of unthinned controls was confounded. Instead, control measurement subplots were established in the extensive unthinned surrounds. 


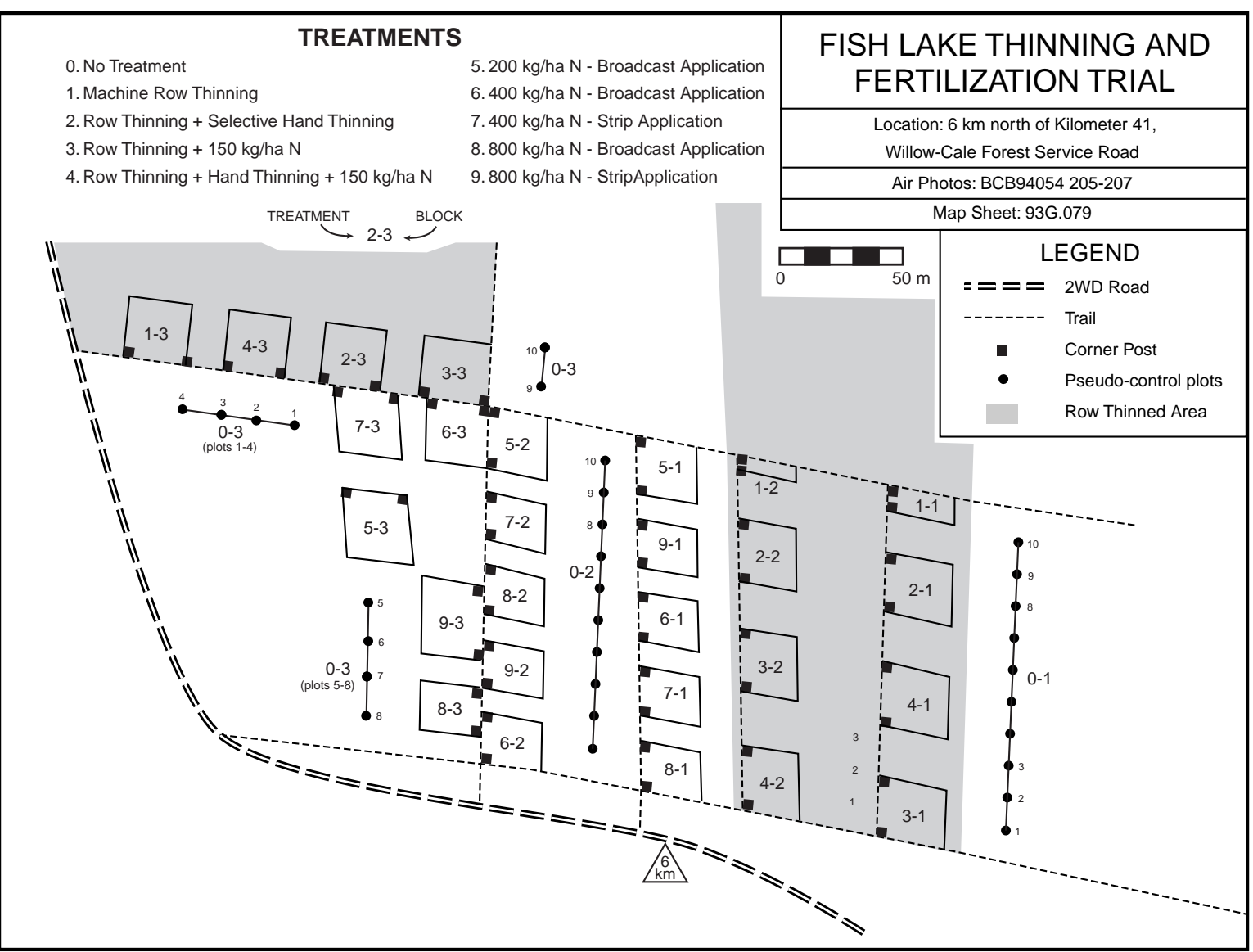

Fig. 1. Site map of the Fish Lake thinning and fertilization trials.

\section{Measurement and Analysis 1979/1980}

Measurements were carried out on both trials after treatment, with block 2 measured in November of 1979 and blocks 1 and 3 in April 1980 (Herring and Cassar-Torreggiani 1980a, b). In each plot of each treatment, six fixed-area measurement subplots were established and trees marked with numbered aluminum tags. Subplot shape and dimensions were varied by treatment: circular plots were used in broadcast treatments while rectangular plots were used in treatments with linear features such as cut rows or concentrated fertilizer strips. Subplot areas were very small $\left(0.5\right.$ to $\left.5.0 \mathrm{~m}^{2}\right)$ due to very high stand densities. For the row-thinned and row-thinned plus fertilizer treatments, plot area varied by residual strip width.

For the fertilizer thinning trial, the effects of the fertilizer treatments on stand density were assessed over the first six months (block 2 only). The cause of tree mortality was assigned to its major contributing factor (snowshoe hare browsing vs. nitrogen toxicity vs. other).

A limited amount of stem analysis was done in 1979 to determine the growth potential of the site and to assess the impact of stand density on height growth. Within the vicinity of the trial, plots were located in portions of the stand growing at different densities, and a top height tree from each plot was dissected to determine height growth patterns. Also selected for analysis were two snags to analyze growth patterns in the original pre-fire lodgepole pine stand.

\section{Measurements}

Measurements were taken in each treatment plot to evaluate growth based on top height and height increments. Based on a visual estimate, the tallest five trees in the central $500 \mathrm{~m}^{2}$ of each treatment plot (the entire plot in some cases) were selected as a sample of the largest 100 trees/ha. On each tree, measures included total height, diameter at breast height (dbh), length of the first five full internodes above breast height, length of the first five full internodes above $2.5 \mathrm{~m}$, and length of the last five internodes (including the 1998 leader). Some measurement error is likely in the five-year internode measurements due to uncertainty in distinguishing nodal branches from internodal branches.

Measurements were also taken to evaluate stand density. In the 1979/80 evaluation, density measures were based on six permanent subplots in each treatment plot. Due to the large span of time since the last measurement and the large changes that have occurred, the original subplots were considered inadequate for the 1998 remeasurement. Instead, a set of 10 temporary subplots was used to sample each treatment plot. New subplots for the untreated pseudo-controls were located in the same vicinity as the original subplots based on map references and old plot locations found in the field.

Each subplot had an area of $18 \mathrm{~m}^{2}$ (sufficient to sample at least 64 trees in each treatment plot for the least dense treatment) in which all live trees were counted. Except in control areas where circular subplots were used, all subplots were rect- 
angular. For treatments with linear features, plot ends were aligned with the edges of cut/fertilized swaths to ensure properly proportioned sampling of treated vs. untreated portions.

\section{Analysis}

Treatment differences were analyzed mainly based on top height and growth rates of the top height trees at various periods since treatment, and on current stand density. To overcome differences in expected growth rates at different tree heights, five-year internode measurements were converted to site index values using a derivation of the B.C. Ministry of Forests growth intercept equations (Nigh 1995). Using this method, site index values could be calculated based on any reference height instead of the normally used breast height $(1.3 \mathrm{~m})$.

An attempt was also made to evaluate differences based on the average height of the largest 2000 trees/ha, but the results were highly suspect. The largest sample trees frequently occurred in a single clump as opposed to being uniformly distributed through the stand. In the control areas, they frequently occurred in one or two of the 10 subplots in one part of the stand.

For each of the tree and stand parameters of interest, analysis of variance was used to test the null hypothesis of no difference between treatment means. Where the null hypothesis was rejected, Tukey's honestly significant difference (HSD) test was used to determine the likelihood of differences between individual pairs of means. All data analysis was done within the Microsoft ${ }^{\circledR}$ Excel 98 (Macintosh) environment, using either built-in or custom functions. Formulas for statistical tests were taken from Weimer (1993) and Winer (1971).

\section{Simulation of Future Benefits}

Potential yield benefits of treatment were explored using TASS ${ }^{4}$ simulations, where projections of future growth for treatments 4 and 6 were compared to that of the control. To make these comparisons, the following assumptions had to be made:

1. Highly dense repressed stands will follow a height over age curve similar to that of an unrepressed stand on a poorer site.

2. Once released from repression, a treated top height tree will follow a similar height over time trajectory as an unrepressed top height tree, using current height rather than age as the basis for determining expected height increment.

3. Once released from repression, a treated stand will follow a similar pattern of development as an unrepressed, untreated stand with a similar density and top height. It is expected that this assumption will lead to slightly overestimated yields for the treated stand, since the unrepressed, untreated surrogate stand will have larger tree diameters and larger, healthier crowns than the formerly repressed, released stand. Such differences have been minimized in this case by using a point of comparison not at the time of treatment but from two decades after the treatment using measured stand statistics. Differences in crown volume are expected to decline with time, particularly after crown closure.

4. TASS can acceptably project stand development patterns for stands at very high densities. Note that there are very limited data to support patterns of stand dynamics for such stands.

\footnotetext{
${ }^{4}$ Tree And Stand Simulator: an individual tree distance dependant growth model developed by Research Branch, BC Ministry of Forests.
}

Given the uncertainty in these assumptions, absolute yield values for the three scenarios should be interpreted with caution. It is proposed, however, that the general magnitude of differences should be reasonable.

\section{Results \\ 1979/1980 Measurements}

The primary value of the $1979 / 80$ measurements is to describe post-treatment conditions relative to the various treatments, and the short-term impacts of some of the treatments on density. Ancillary measures of site index on areas immediately adjacent to the study also provide a useful baseline comparison for treatment impacts.

Post-treatment densities and six-month mortality rates (Brkich 1981) for the controls and treatments 5 through 9 are summarized in Table 2. Mortality rates ranged from $10 \%$ on the control area to $89 \%$ on the $800-\mathrm{kg} / \mathrm{ha} \mathrm{N}$ (broadcast) treatment. Increased mortality, caused both by snowshoe hare browsing and by urea toxicity, was associated with increasing levels of nitrogen application. It is important to note that snowshoe hares in the area were at the peak of a local population cycle, and that tree mortality trends in the absence of hares can only be speculated.

Post-treatment density measures for treatments 3 (row plus hand thin) and 4 (row thin plus hand thin plus fertilizer) treatments averaged 7667 and 6778 trees per hectare respectively. Similar measures are not available for treatments 1 and 2 due to missing plot size information, but assuming a pre-treatment density similar to the controls, a $2.5-\mathrm{m}$ cut swath and a $2.0-\mathrm{m}$ residual strip, we can estimate these values at 112000 tree/ha.

Two snags analyzed through stem dissection in 1979/80 suggest site index values of 15 and 22 (based on measured height at breast height age 50), although it is doubtful that the former was actually a top height tree in the original stand. Also in 1980, a series of height growth by stand density plots (Fig. 2) were assessed which, when analyzed using current height intercept models (Nigh 1995), suggest an unrepressed site index for the site of 19 metres.

\section{Measurements}

Basic descriptive statistics for each treatment are provided in Table 3. In most cases, differences between treatments were so large as to be visually obvious (Fig. 3).

Differences in growth potential between treatments were evaluated based on top height, the length of the first five internodes above breast height, the length of the first five internodes above $2.5 \mathrm{~m}$, and the last five years of height growth (Fig. 4). Treatment differences were detected for all four parameters evaluated. In all cases, analysis of variance resulted in rejection of the null hypothesis $\left(\mathrm{H}_{0}: \mathrm{T}_{0}=\mathrm{T}_{1}=\mathrm{T}_{2} \ldots=\mathrm{T}_{9}\right)$ at the $95 \%$ level of confidence (Table 4).

Similar differences were detected between individual pairs of treatments regardless of measurement parameter (Fig. 5), although fewer differences were found for the 1.3-m growth intercept figures. In all cases except the earliest growth increments, the two best treatments were row plus hand thinning plus $150 \mathrm{~kg} / \mathrm{ha} \mathrm{N}$ and $800 \mathrm{~kg} / \mathrm{ha} \mathrm{N}$ applied in broadcast form. This was followed closely by $800 \mathrm{~kg} / \mathrm{ha} \mathrm{N}$ applied in concentrated strips, then with slightly poorer results by the two $400 \mathrm{~kg} / \mathrm{ha}$ $\mathrm{N}$ applications. Depending on the measurement parameter, there was either no significant difference or a very small difference 
Table 2. Summary of density trends over the first six months in the non-thinned treatments. Top values in each cell represent mortality as trees/ha, while values in parentheses are mortality as percentage of the pretreatment (1979) density

\begin{tabular}{|c|c|c|c|c|c|c|c|}
\hline Treatment & $\begin{array}{l}\text { Ave. density } \\
\text { (living) } \\
1979\end{array}$ & $\begin{array}{c}\text { Ave. number } \\
\text { killed since } \\
1979\end{array}$ & $\begin{array}{l}\text { Ave. number } \\
\text { killed by hares }\end{array}$ & $\begin{array}{c}\text { Death by } \\
\text { natural causes } \\
\& / \text { or urea }\end{array}$ & $\begin{array}{c}\text { Death by } \\
\text { urea }\end{array}$ & $\begin{array}{l}\text { Ave. number } \\
\text { hare topped }\end{array}$ & $\begin{array}{c}\text { Ave. density } \\
\text { living trees } \\
1980\end{array}$ \\
\hline 0. Control & 280000 & $28333(10.1 \%)$ & $16666(6.0 \%)$ & $11667(4.2 \%)$ & N/A & $65000(23.2 \%)$ & 251667 \\
\hline $5.200 \mathrm{~kg} / \mathrm{ha} \mathrm{N}$ broadcast & 326667 & $56667(17.3 \%)$ & $24444(7.5 \%)$ & $32223(9.9 \%)$ & $20556(6.3 \%)$ & $54444(16.7 \%)$ & 270000 \\
\hline 6. $400 \mathrm{~kg} / \mathrm{ha} \mathrm{N}$ broadcast & 296470 & $100000(33.7 \%)$ & $49412(16.7 \%)$ & $50588(17.1 \%)$ & $38920(13.1 \%)$ & $100000(33.7 \%)$ & 196470 \\
\hline 7. $400 \mathrm{~kg} / \mathrm{ha} \mathrm{N}$ strip & 316842 & $109474(34.6 \%)$ & $65263(20.6 \%)$ & $44211(14.0 \%)$ & $32544(10.3 \%)$ & $106316(33.6 \%)$ & 207368 \\
\hline $8.800 \mathrm{~kg} / \mathrm{ha} \mathrm{N}$ broadcast & 243333 & $216667(89.0 \%)$ & $152222(62.6 \%)$ & $64445(26.5 \%)$ & $52778(21.7 \%)$ & $184444(75.8 \%)$ & 26666 \\
\hline $9.800 \mathrm{~kg} / \mathrm{ha} \mathrm{N}$ strip & 221053 & $114737(51.9 \%)$ & $67368(30.5 \%)$ & $47369(21.4 \%)$ & $35702(16.2 \%)$ & $104210(47.1 \%)$ & 106316 \\
\hline
\end{tabular}

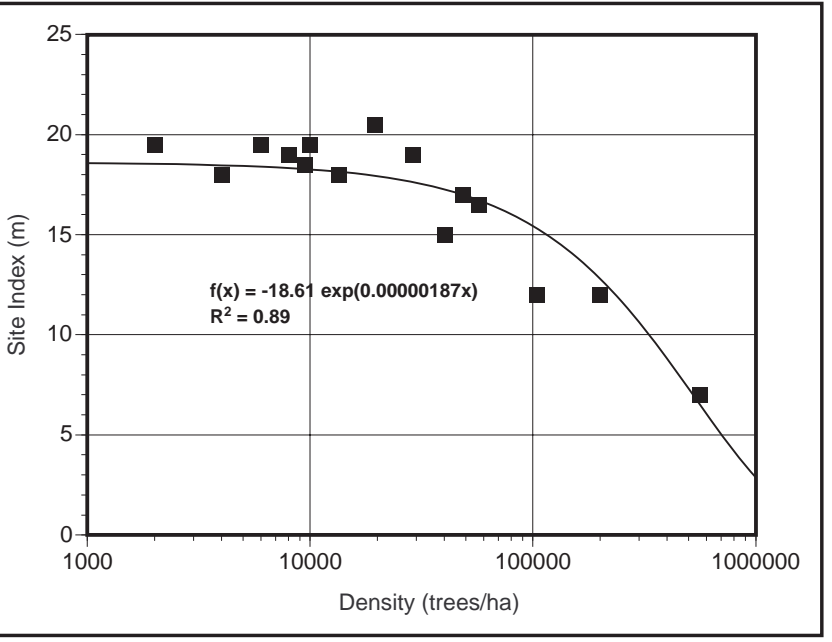

Fig. 2. Measurements from areas of the stand surrounding the trial in 1979 (stand age $=17$ ) indicate a close relationship between establishment density and growth rates. The stated co-efficient $\left(\mathrm{r}^{2}\right)$ should be regarded with caution, as the sampling was heavily skewed to the lower densities.

between the control and the row thinning, row plus hand thinning, row thinning plus $150 \mathrm{~kg} / \mathrm{ha} \mathrm{N}$, and $200 \mathrm{~kg} / \mathrm{ha} \mathrm{N}$ treatments.

Values for the last five-year growth period are the only ones that reflect entirely the post-response growth potential, and the only ones free of the assumption that all treatment plots had similar top height trees at the time of establishment. The five-year growth period starting immediately above breast height reflects mostly the pre-treatment period, since the largest trees at the time of treatment were often in excess of $1.5 \mathrm{~m}$ in height. Despite this, there were a few trees, particularly in treatments 4,8 and 9 , that showed evidence of some treatment response during this period. Similarly, there were some trees just starting to achieve noticeable increases in growth during the five-year period above $2.5 \mathrm{~m}$. While this was interpreted in the field as variations in the time to response after treatment, at least some of this effect could be attributable to differences in height at the time of treatment. Differences in top height from plot to plot at the time of treatment could also affect interpretations based on current top height. Despite these problems, the magnitude of tree and stand differences between treatments for all measurement parameters suggest that the results are real.

There was considerable variability in height throughout the control areas, both in terms of predominant canopy height (visual estimate of dominants and codominants) and top height. The predominant height of the canopy in control areas varied from approximately 2.5 to $5 \mathrm{~m}$. Top height varied less (4-6 m), but followed a similar pattern. Top height trees were frequently $2 \mathrm{~m}$ above the main canopy, and occasionally 3-4 $\mathrm{m}$ above, while in the treated plots this difference was seldom greater than 1-2 m.

Two of the treatment strategies in this study employed some form of linear thinning. Row thinning, the more intensive and consistent of the two, removed approximately $60 \%$ of existing stems in $2.5-\mathrm{m}$ cut swaths. Fertilizer applications in concentrated strips were intended to kill trees along the strip thereby releasing and fertilizing the surviving trees closer to the midpoint between strips. It was originally anticipated that both of these treatments would produce a differential growth effect depending on the proximity of an individual tree to the treated strip. Evaluations based on proximity to these treatment strips failed to show a significant difference in the post-treatment growth between edge and interior trees based on average height of dominant and codominant trees. An attempt was made to evaluate the relative frequency of dominant and codominant trees between edge and interior positions, but there was insufficient precision in the data collection to properly proportion the relative areas assessed as interior vs. edge.

Further estimates of unrepressed growth potential for the site over those made in 1980 were undertaken in 1998: three trees in an adjacent unrepressed patch were assessed, and a comparison was made to a BC Ministry of Forests correlation of site series to site index (Anon. 1997). Both of these sources suggest a site index of approximately $19 \mathrm{~m}$, which is only slightly higher than the apparent site index of $17.5 \mathrm{~m}$ resulting from the best of the treatments. The apparent site index in the controls of $9.5 \mathrm{~m}$ continues to agree with that suggested in Fig. 2 assuming an establishment density of 250000 trees/ha.

Current stand density figures are listed in Table 3 , with the highest densities still found in the control areas. Using analysis of variance, a statistically significant treatment effect was found (Table 5). When all trees are considered, densities are statistically indistinguishable (using Tukey's HSD test) between the unthinned control and treatment $5(200 \mathrm{~kg} / \mathrm{ha} \mathrm{N}$ - broadcast), and between several other treatment pairs exclusive of the control. Much of the variation, however, is introduced by large plot-to-plot differences in the numbers of very small trees. If only the trees greater than $1.3 \mathrm{~m}$ in height are considered, there is a significant difference between all pairs of treatments except 1 and 6 (row thinning and $400 \mathrm{~kg} / \mathrm{ha} \mathrm{N}$ - broadcast), a similarity that seems coincidental rather than the result of similar treatment effects. Stand densities are lowest either where hand thinning reduced the density at the time of treatment, or where the highest levels of urea applications were employed. 


\begin{tabular}{|c|c|c|c|c|c|}
\hline Treatment & $\begin{array}{l}\text { Top Height } \\
\text { (m) }\end{array}$ & $\begin{array}{l}\text { Site Index* } \\
\text { (m) }\end{array}$ & $\begin{array}{l}\text { Density } \\
\text { (trees/ha) }\end{array}$ & $\begin{array}{l}\text { Mean Height } \\
(\mathrm{m})\end{array}$ & $\begin{array}{c}\text { Mean Height Top } \\
2000(\mathrm{~m})\end{array}$ \\
\hline 0 & $\begin{array}{l}4.8 \\
(0.22)\end{array}$ & $\begin{array}{l}9.6 \\
(0.12)\end{array}$ & $\begin{array}{l}44796 \\
(2179)\end{array}$ & $\begin{array}{l}2.5 \\
(0.15)\end{array}$ & $\begin{array}{l}4.7 * * \\
(0.58) * *\end{array}$ \\
\hline 1 & $\begin{array}{l}4.7 \\
(0.15)\end{array}$ & $\begin{array}{l}11.2 \\
(0.85)\end{array}$ & $\begin{array}{l}36000 \\
(4311)\end{array}$ & $\begin{array}{l}2 \\
(0.1)\end{array}$ & $\begin{array}{l}3.9 \\
(0.31)\end{array}$ \\
\hline 2 & $\begin{array}{l}5.5 \\
(0.64)\end{array}$ & $\begin{array}{l}12.1 \\
(0.34)\end{array}$ & $\begin{array}{l}25389 \\
(9271)\end{array}$ & $\begin{array}{l}1.3 \\
(0.22)\end{array}$ & $\begin{array}{l}3.8 \\
(0.45)\end{array}$ \\
\hline 3 & $\begin{array}{c}6.2 \\
(0.38)\end{array}$ & $\begin{array}{l}12.4 \\
(1.4)\end{array}$ & $\begin{array}{l}31944 \\
(1078)\end{array}$ & $\begin{array}{l}2.7 \\
(0.19)\end{array}$ & $\begin{array}{l}5.3 \\
(0.38)\end{array}$ \\
\hline 4 & $\begin{array}{l}7.8 \\
(0.06)\end{array}$ & $\begin{array}{l}17.5 \\
(0.28)\end{array}$ & $\begin{array}{c}6870 \\
(964)\end{array}$ & $\begin{array}{l}3.8 \\
(0.47)\end{array}$ & $\begin{array}{l}6.5 \\
(0.09)\end{array}$ \\
\hline 5 & $\begin{array}{c}5.2 \\
(0.12)\end{array}$ & $\begin{array}{l}10.1 \\
(0.09)\end{array}$ & $\begin{array}{l}41278 \\
(7163)\end{array}$ & $\begin{array}{c}2.9 \\
(0.09)\end{array}$ & $\begin{array}{c}4.3 \\
(0.2)\end{array}$ \\
\hline 6 & $\begin{array}{l}6.8 \\
(0.45)\end{array}$ & $\begin{array}{l}14.4 \\
(1.17)\end{array}$ & $\begin{array}{l}34111 \\
(1695)\end{array}$ & $\begin{array}{l}3.9 \\
(0.2)\end{array}$ & $\begin{array}{l}6.1 \\
(0.35)\end{array}$ \\
\hline 7 & $\begin{array}{l}6.6 \\
(0.35)\end{array}$ & $\begin{array}{l}14.5 \\
(1.2)\end{array}$ & $\begin{array}{l}22852 \\
(4371)\end{array}$ & $\begin{array}{l}3.8 \\
(0.15)\end{array}$ & $\begin{array}{l}5.8 \\
(0.52)\end{array}$ \\
\hline 8 & $\begin{array}{l}7.5 \\
(0.25)\end{array}$ & $\begin{array}{l}16.6 \\
(0.58)\end{array}$ & $\begin{array}{l}17648 \\
(3650)\end{array}$ & $\begin{array}{l}4.8 \\
(0.24)\end{array}$ & $\begin{array}{l}6.6 \\
(0.1)\end{array}$ \\
\hline 9 & $\begin{array}{l}7.1 \\
(0.09)\end{array}$ & $\begin{array}{l}15.8 \\
(0.35)\end{array}$ & $\begin{array}{l}16685 \\
(1042)\end{array}$ & $\begin{array}{l}4.4 \\
(0.13)\end{array}$ & $\begin{array}{l}6.2 \\
(0.37)\end{array}$ \\
\hline
\end{tabular}

* Site Index based on last five-year height increment.

** Site variability and sampling design resulted in these values being representative of only the best portion of the site rather than an average for the site as a whole. This problem also existed on the treated plots, but to a lesser extent.

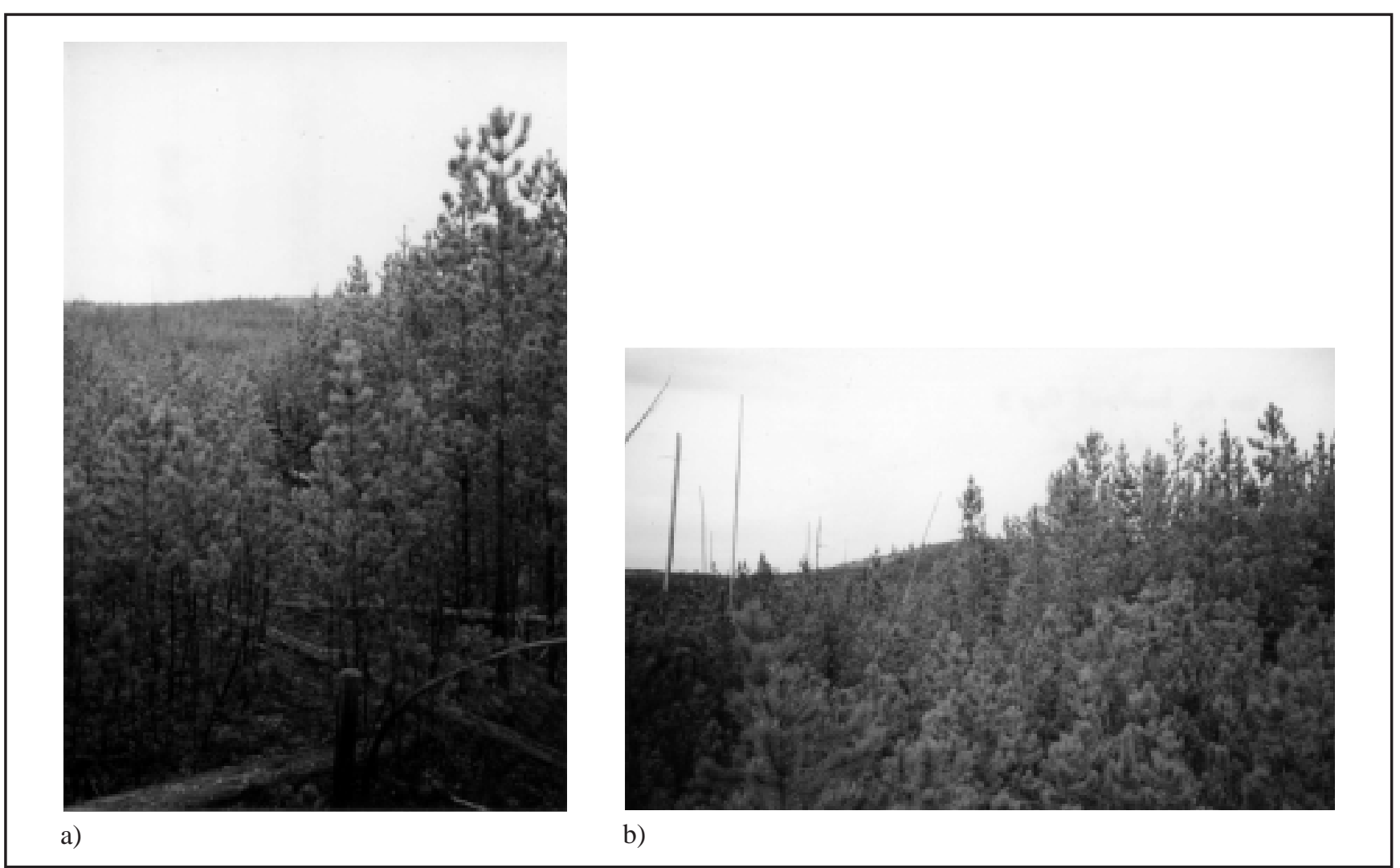

Fig. 3. Top height differences between treated and control stands were obvious. In a), the corner post in the fore ground and the small trail behind it seperate an untreated buffer on the left from the $400 \mathrm{~kg} / \mathrm{ha} \mathrm{N}$ (strip application) plot on the right. Photo b) was taken over the canopy of an untreated area showing the degree to which an $800 \mathrm{~kg} / \mathrm{ha} \mathrm{N}$ treatment plot (right side) rises above the untreated surround

All treatments in the row thinning trial had some small mid-swath trees that were obviously missed during treatment. Stand densities in the row plus hand thinning plots, however, appear to be much higher than expected given the prescribed post-treatment density. A large percentage of these trees are very small and are not noticeably competing with those selected during the hand thinning operation. While similar small trees exist in other treatments, they occur with much less frequen- 

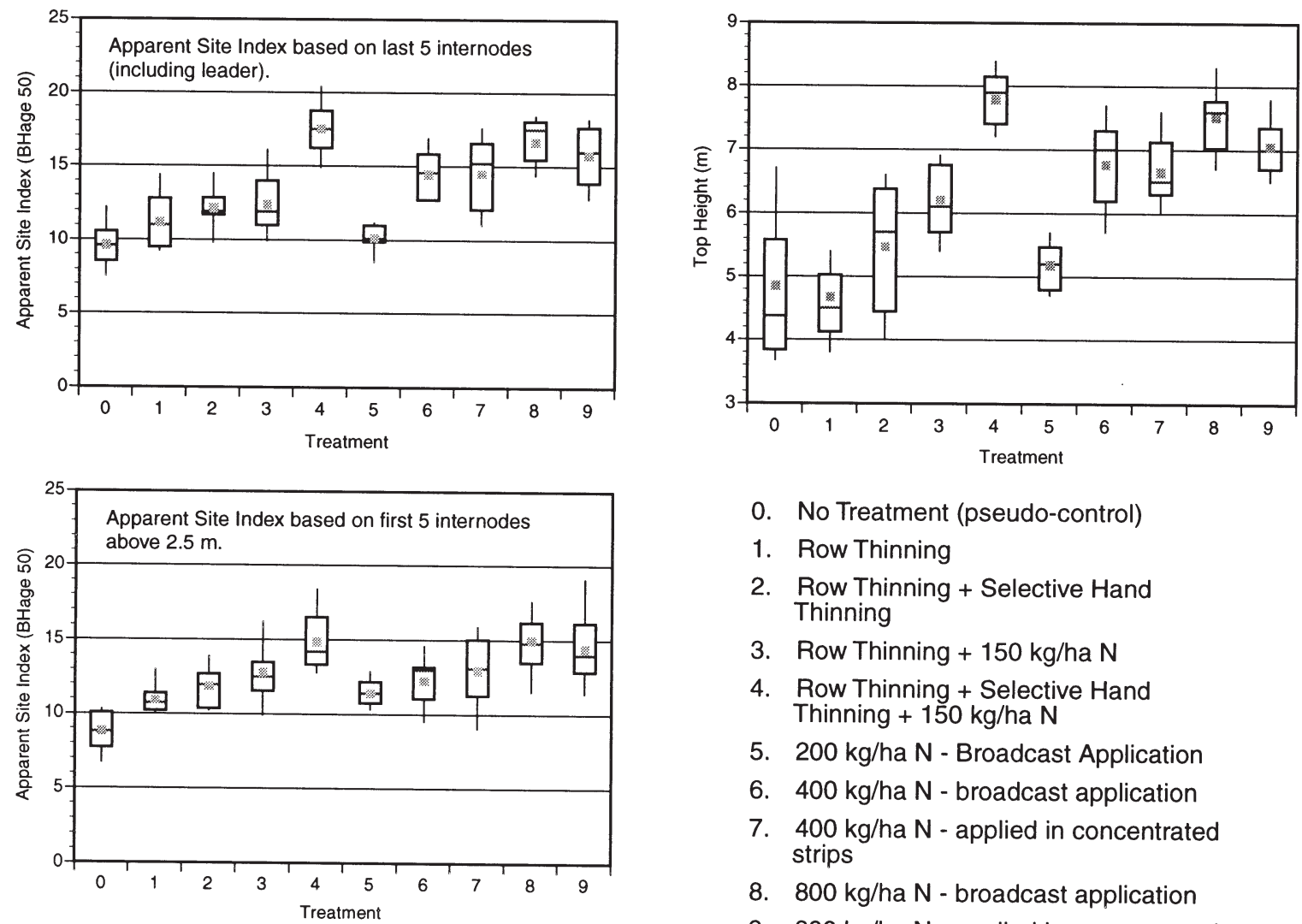
0. No Treatment (pseudo-control)
1. Row Thinning
2. Row Thinning + Selective Hand Thinning
3. Row Thinning $+150 \mathrm{~kg} / \mathrm{ha} \mathrm{N}$
4. Row Thinning + Selective Hand Thinning $+150 \mathrm{~kg} / \mathrm{ha} \mathrm{N}$
5. $200 \mathrm{~kg} / \mathrm{ha} \mathrm{N}$ - Broadcast Application
6. $400 \mathrm{~kg} / \mathrm{ha} \mathrm{N}$ - broadcast application
7. $400 \mathrm{~kg} / \mathrm{ha} \mathrm{N}$ - applied in concentrated strips
8. $800 \mathrm{~kg} / \mathrm{ha} \mathrm{N}$ - broadcast application
9. $800 \mathrm{~kg} / \mathrm{ha} \mathrm{N}$ - applied in concentrated
strips

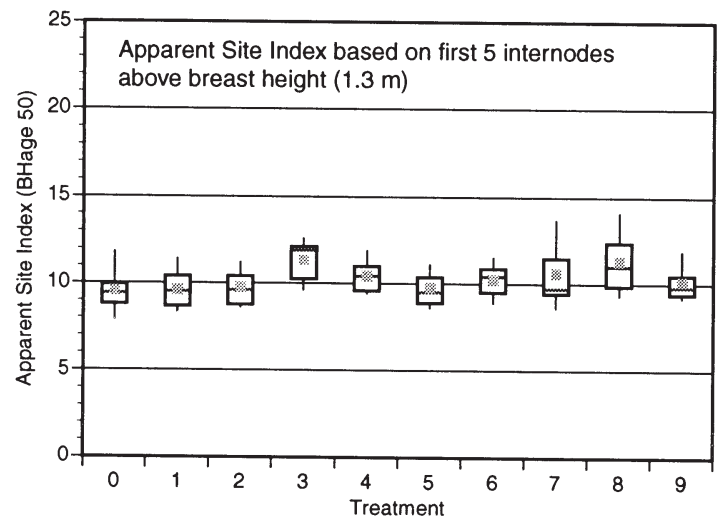

Fig. 4. Distribution of data used to determine top height and site index. Each box represents combined data for all three blocks of each treatment (15 trees). Upper and lower limits of box show 75th and 25th percentiles respectively, while the ends of the whiskers show the 90th and 10th percentiles. The line through the box shows the median, while the square grey symbol shows the arithmetic mean.

cy. Initially, it was believed that these trees resulted from post-treatment regeneration. Of note, however, were the observations of one visitor to the site: based on branch traces in the pith it was suggested that these trees were established prior to the treatment date. It is possible, therefore, that these trees were small enough to have been missed during the original row thinning and subsequent hand thinning treatments, or have grown up from basal live limbs.

Some density variation exists within treatment plots. In many of the fertilizer thinning trial plots, it was noted that plot portions furthest from access trails were frequently less dense than nearer the trail. This effect was confirmed using difference of means $t$-tests $(\mathrm{p}=0.05)$ for blocks 2 and 3 , but no difference was found in block 1. It was speculated in the field that this may be the result of differences in preferred cover habitat and hare feeding intensity. In block 1 , the access trail was much narrower than for blocks $2 \& 3$, which may have reduced this effect.

\section{Potential Benefits}

Expected yield trends for two treated stands and the untreated stand are illustrated in Fig. 6. Yields for the row plus hand thinning plus $150 \mathrm{~kg} / \mathrm{ha} \mathrm{N}$ treatment are likely near the maximum that can be expected following treatment of this stand, while the $400 \mathrm{~kg} / \mathrm{ha} \mathrm{N}$ treatment represents an intermediate result. 
Table 4. Analysis of variance of top height and estimated site index, 19 years after treatment

\begin{tabular}{|c|c|c|c|c|c|c|c|c|c|c|c|c|c|}
\hline \multicolumn{7}{|c|}{ Top height } & \multicolumn{7}{|c|}{ SI - Last 5-year increment } \\
\hline $\begin{array}{l}\text { Source of } \\
\text { variation }\end{array}$ & $S S$ & $d t$ & MS & $\boldsymbol{F}$ & $P$-value & $F$-crit & $\begin{array}{l}\text { Source of } \\
\text { variation }\end{array}$ & $S S$ & $d t$ & $M S$ & $\boldsymbol{F}$ & $P$-value & $F$-crit \\
\hline Treatment & 33.64 & 9 & 3.74 & 18.28 & 0.0000003 & 2.46 & Treatment & 205.53 & 9 & 22.61 & 13.27 & 0.0000030 & 2.46 \\
\hline Block & 2.64 & 2 & 1.32 & 6.45 & 0.0077 & 3.55 & Block & 6.53 & 2 & 3.27 & 1.92 & 0.18 & 3.55 \\
\hline Error & 3.68 & 18 & 0.20 & & & & Error & 30.68 & 18 & 1.70 & & & \\
\hline Total & 39.96 & 29 & & & & & Total & 240.74 & 29 & & & & \\
\hline \multicolumn{7}{|c|}{ SI - 5-year increment above $2.5 \mathrm{~m}$} & \multicolumn{7}{|c|}{ SI - 5-year increment above $1.3 \mathrm{~m}$} \\
\hline $\begin{array}{l}\text { Source of } \\
\text { variation }\end{array}$ & SS & $d t$ & MS & $\boldsymbol{F}$ & $P$-value & $F$-crit & $\begin{array}{l}\text { Source of } \\
\text { variation }\end{array}$ & SS & $d t$ & $M S$ & $\boldsymbol{F}$ & $P$-value & $F$-crit \\
\hline Treatment & 99.94 & 9 & 11.10 & 12.58 & 0.00000044 & 2.46 & Treatment & 11.47 & 9 & 1.27 & 3.80 & 0.0077 & 2.46 \\
\hline Block & 1.59 & 2 & 0.79 & 0.90 & 0.42 & 3.55 & Block & 0.65 & 2 & 0.32 & 0.97 & 0.40 & 3.55 \\
\hline Error & 15.89 & 18 & 0.88 & & & & Error & 6.04 & 18 & 0.34 & & & \\
\hline Total & 117.42 & 29 & & & & & Total & 18.15 & 29 & & & & \\
\hline
\end{tabular}

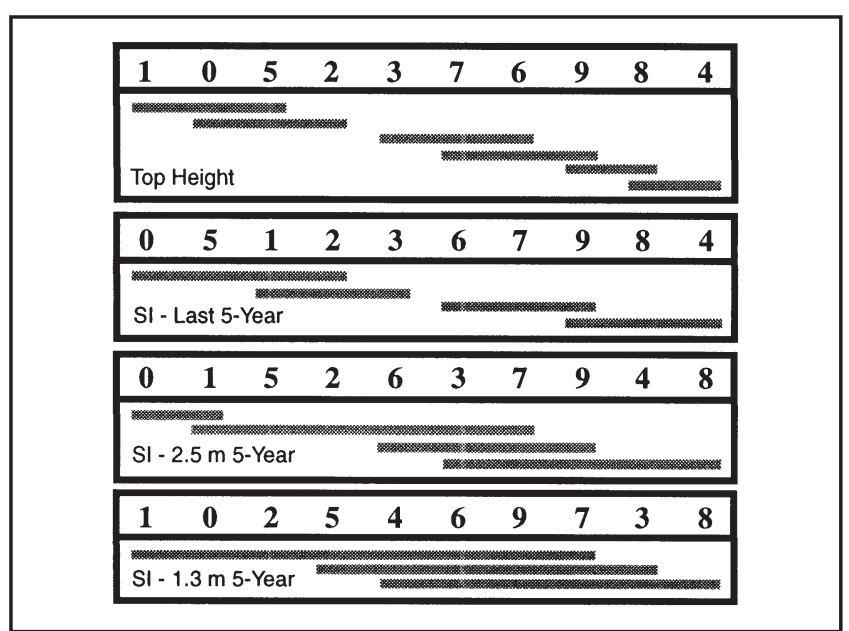

Fig. 5. Separation of means using Tukey's HSD multiple comparison test. Treatment numbers not underlined by a single bar are considered to be from different populations. This test is considered to be conservative in terms of detecting differences between means (it will more frequently miss detecting a difference that does exist than it will indicate a difference that does not exist).

Yields for the $800 \mathrm{~kg} / \mathrm{ha} \mathrm{N}$ treatments would be slightly less than for the best treatment. Expected yields are not only up to $350 \%$ greater on the treated stands than on the untreated areas, but merchantable yields are achieved at a much earlier age. This last factor can be extremely important where there are projected fibre supply shortfalls at specific periods in the future.

\section{Discussion}

\section{Treatment Effects}

The results of this study suggest that stand treatment has the capability of dramatically improving long-term height growth in severely repressed lodgepole pine stands. In the best treatment, top height has been increased by 3 m over the controls in 18 years, while the apparent site index (reference age 50) increased almost 8 metres. Such growth responses can shorten the current rotation, increase current-rotation mean annual increment, and increase piece sizes at harvest.

The best growth responses were observed where density management and fertilization were combined (Fig. 7). Where these treatments were applied independently, gains in height growth were relatively small. In the high dose $(400$ and $800 \mathrm{~kg} / \mathrm{ha}$ $\mathrm{N}$ ) fertilizer treatments, the density reduction was achieved through a combination of urea toxicity and snowshoe hare feeding.

The high level of density reduction caused by hare feeding resulted at least partially from fertilizing at the peak of the snowshoe hare population cycle. Also, hare-related mortality in these trials may have been greater than would be experienced operationally due to concentration of feeding activity within a limited treatment area. The difference in frequency of small trees between the row plus hand thinning and the row plus hand plus fertilizer treatments may also have been a function of hare feeding: where the residual mid-swath small trees were fertilized they would have been much more attractive as a food source.

Row thinning in general was a much less effective treatment than those which achieved more uniform inter-tree spacing. For example, the addition of selective hand thinning resulted in larger height growth increases than row thinning alone (Fig. 4). Row thinning plus $150 \mathrm{~kg} / \mathrm{ha} \mathrm{N}$ achieved greater stand density reductions immediately after treatment than the $400 \mathrm{~kg} / \mathrm{ha} \mathrm{N}$ treatments, but resulted in a height growth response of lesser magnitude. While the two levels of fertilizer are not the same in this comparison, the excellent results of the row plus hand thinning plus $150 \mathrm{~kg} / \mathrm{ha} \mathrm{N}$ suggest that the higher level of nitrogen was not required if accompanied by appropriate density control.

Compared to the unthinned control, row thinning actually appears to have enhanced survivorship of the remaining trees. Over the 19 years since treatment, the mean stand density of control subplots has been reduced from 280000 trees/ha to 45000 , while the row thinned area has been reduced from 112000 to 36000 trees/ha. While the mean density for the row-thinned area is lower in absolute numbers, most trees there have less growing space than in the control areas. For example, in row thinned plots approximately $60 \%$ of the growing space is in cut swaths, which remain largely unoccupied by tree crowns. This spatial anomaly leaves most of the residual trees competing to occupy $40 \%$ of the above-ground growing space. The original treatment assumption that trees on the edge of the cut swaths would benefit from the extra growing space does not appear to have held true-there is no height growth evidence from this trial to suggest that the best edge trees have a competitive advantage over the best trees in the middle of the residual strip. 
Table 5. Analysis of variance of density 19 years after treatment

\begin{tabular}{|c|c|c|c|c|c|c|}
\hline \multicolumn{7}{|l|}{ All Trees } \\
\hline Source of variation & $S S$ & $d t$ & $M S$ & $F$ & $P$-value & $F$-crit \\
\hline Between treatments & 3869097634 & 9 & 429899737.1 & 7.20 & 0.00013 & 2.39 \\
\hline Within treatments & 1194454733 & 20 & 59722736.63 & & & \\
\hline Total & 5063552366 & 29 & & & & \\
\hline \multicolumn{7}{|l|}{ Trees $>1.3 \mathrm{~m}$ tall } \\
\hline Source of variation & $S S$ & $d t$ & $M S$ & $\boldsymbol{F}$ & $P$-value & $F$-crit \\
\hline Between treatments & 4508195062 & 9 & 500910562.4 & 16.11 & 0.00000025 & 2.39 \\
\hline Within treatments & 622039095 & 20 & 31101954.73 & & & \\
\hline Total & 5130234156 & 29 & & & & \\
\hline
\end{tabular}
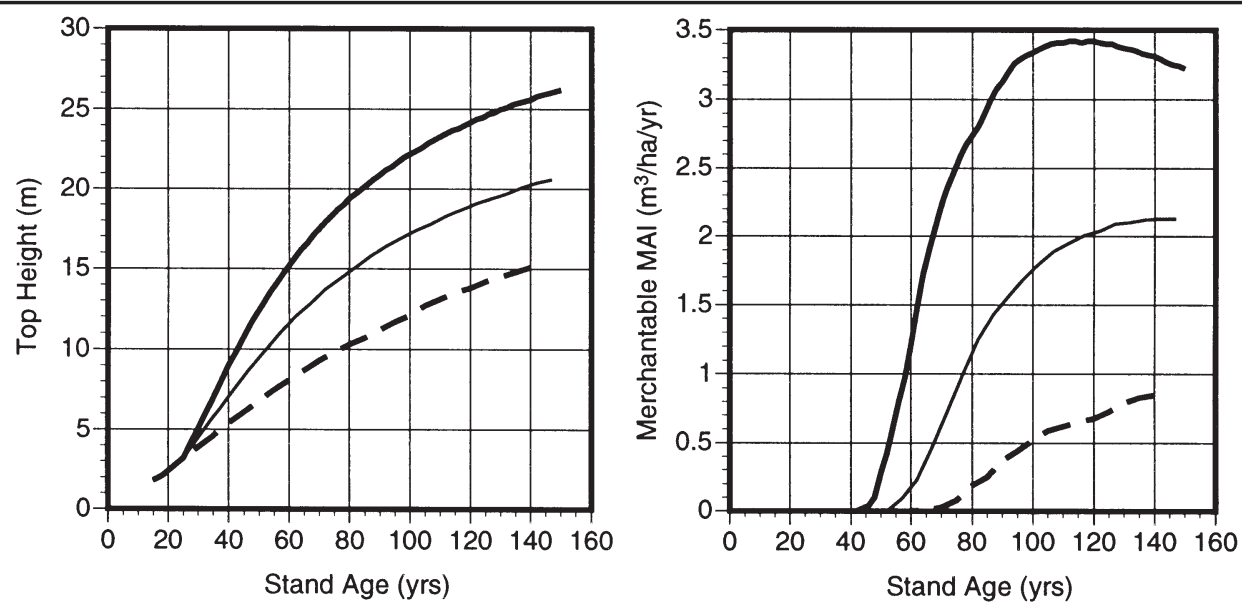

Fig. 6. Potential yields from three different treatment scenarios. The curve shapes for the treated stands are similar to those of stands on the same site which were never reppressed - the same values just occur at later ages. Values in these graphs represent those predicted by TASS for healthy stands with no pest losses and in unstocked gaps. Volumes are net of stumps, tops and nonmerchantable stems (less than $12.5 \mathrm{~cm} \mathrm{dbh}$ ), but no deductions have been made for decay, waste or breakage.

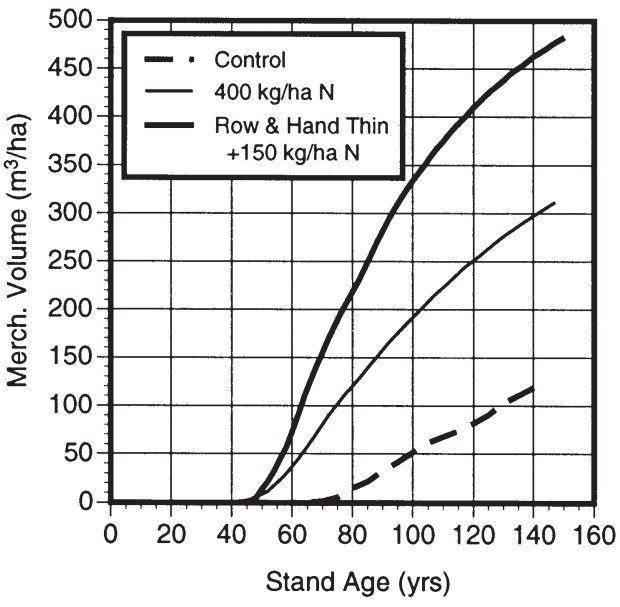

\section{Comparison to Other Studies}

While the magnitude of height growth response in this trial is rare it is not unprecedented. Unfortunately, the majority of published works in repressed lodgepole pine stands deal only with thinning - few other studies were found which combined thinning and fertilizer treatments in severely repressed lodgepole pine stands.

One case of a similar response was reported by Smithers (1957), who observed large and dramatic height growth effects from thinning a very young (five-year old) stand established at extremely high densities (1.25 million per hectare), presumably by avoiding the onset of repression. He found no measurable height growth effects, however, in similar thinned stands aged 13 to 73 years.
Moderate height gains were found in a few studies in older stands. Bella and De Franceschi (1982) found a weakly significant $35 \%$ gain in height growth for an unspecified component of the largest trees in a mechanically strip-thinned stand. J.S. Thrower and Assoc. (1993) found several cases where operationally thinned lodgepole pine stands had greater height growth (up to $30 \%$ ) than surrounding untreated stands with presumably similar sites and pre-treatment stand conditions. Goudie (1980) documented several cases where individual trees had been released from repression at the edges of burns, in single-tree thinning trials and along the edges of road rights-of -way.

In still other cases, height growth responses to thinning were small or non-existent (Alexander 1965; Dahms 1971; Johnstone 1981a, b; Johnstone 1982). Alexander (1960) found 


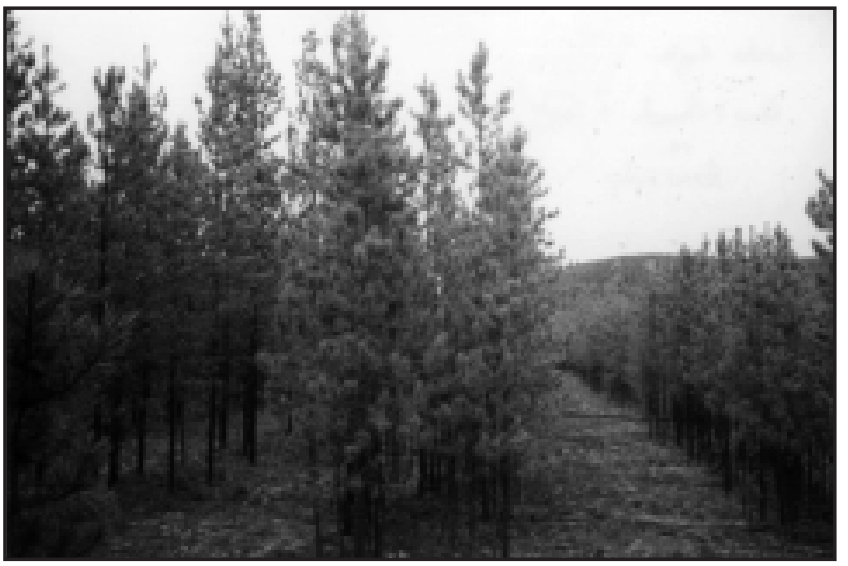

Fig. 7. A row plus hand thinned plus $150 \mathrm{~kg} / \mathrm{ha} \mathrm{N}$ plot (block 3 ) on the left contrasted with an adjacent area which was only row thinned.

quite variable response, with one block experiencing a large positive response while others had negative responses. Three cases of overall negative responses have been reported for a short period after thinning (Tackle and Shearer 1959—cited by Lotan 1967, Dahms 1973, Johnstone 1981b) but in at least two of these cases the effect disappeared after a longer period (Lotan 1967, Johnstone 1981b). In many cases, the inability to measure heights accurately was blamed for an inability to detect possible responses.

A variable that was difficult to asses in these comparisons was the level of repression in the unthinned stands and thus the potential for a height gain if the treatment was effective at removing the repression-related barriers to height growth. Most of the studies quoted described the unthinned stands in a qualitative sense as overly dense or over-stocked, but no reliable measure of repression has been employed, so no effective comparisons can be made.

Fertilization alone in the Fish Lake trial has resulted in small but sustained positive effects on height growth. When combined with some form of density control, the height growth gains were large and sustained. Operational fertilization of lodgepole pine generally produces positive gains in diameter growth but has only small if any effect on height (Cochran 1989, Brockley 1990, Marshall et al. 1992, Sullivan 1999). Where height responses do occur, they are limited in duration, usually to less than one decade. It should be noted, however that virtually all operational and research experience with fertilizers in lodgepole pine has been in previously thinned stands, and that the presence or absence of previous repression effects can only be speculated.

The observed height growth responses in the Fish Lake trial appear initially to deviate dramatically from a large body of operational and research fertilization experience. Few, however, of the operational and research trials have been in repressed stands. Where fertilizing an unrepressed stand results in a brief height growth increase followed by a return to "normalcy," the same treatment in a repressed but thinned stand results in a trend back to "normalcy," or the true site potential.

Unfortunately, the Fish Lake study does not contribute significantly to our understanding of the causal mechanisms of repres- sion, but may suggest avenues for future studies. The effectiveness of thinning and fertilization could, for example, suggest simply a supply-side issue, where better nutrition coupled with an associated improvement in water-use efficiency has led to better growth. There may, however, still be alternate explanations. We now know with some certainty that repression is not a permanent phenomena, and that cultural treatments can be effective in returning trees to a more normal pattern of growth. We still do not, however, have sufficient understanding of repression to make consistent and effective prescriptions for treatment.

\section{Conclusions}

A combination of thinning and fertilization has the potential to dramatically increase height growth and yield from severely repressed lodgepole pine stands. In this study, there appears to be a very large differential rate of height growth between the untreated stand and the best of the treated stands, with an apparent site index difference of almost 8 metres at breast height age 50 . This site has a relatively good site potential at SI50 $=19$, however, and other sites with lower productivity potential may not experience a response range of the same magnitude.

Both thinning and fertilization appear necessary to achieve maximum release from repression. Stands that were only fertilized or only heavily thinned grew better, in most cases, than the untreated stands but not nearly as well as where both treatments were applied. With heavy fertilization rates, there was a synergistic thinning effect that prevented the evaluation of fertilization alone.

Snowshoe hares played a role in density control in this trial. Hare clipping/browsing contributed to observed mortality rates where heavier applications of fertilizer were used. Such effects must be carefully considered in any future applications or trials-it is important to note that the fertilizer effect under these conditions could not be separated from the thinning effect.

While this trial offers significant hope for achieving large yield gains in repressed pine stands, rigid extrapolation of the results to other sites would be speculative at best. Work that is required prior to widespread operational application includes a series of replicated trials on different sites to evaluate the best treatment options under a range of site conditions. One similar trial has been established in the Cariboo Forest Region west of Williams Lake, BC (T. Newsome, personal communication ${ }^{5}$ ), and shows very promising two-year results. Several other installations using similar methods are critical for calibrating treatment prescriptions to local site conditions and to help develop methods of predicting treatment response.

\section{Acknowledgements}

Funding for the re-measurement and data analysis on this trial were provided by Weldwood of Canada Ltd., Hinton Division. Funding for publication has been provided by the BC Ministry of Forests. Valuable input to the sampling design was provided by Stan Navratil of Silfor Consulting.

This paper is dedicated to the memory of Dave Presslee, a respected colleague. Dave was instrumental in generating the interest and providing the funding for this work to be undertaken.

\footnotetext{
${ }^{5}$ Research Silviculturist, Cariboo Forest Region, BC Ministry of Forests.
} 


\section{References}

Alexander, R.R. 1960. Thinning lodgepole pine in the central Rocky Mountains. J. For. 58(2): 99-104.

Alexander, R.R. 1965. Growth of thinned young lodgepole pine in Colorado. J. For. 63(6): 429-433.

Anon. 1997. Site index estimates by site series for coniferous tree species in British Columbia. B.C. Min. Forests, Victoria. SIL418. 265 p.

Bella, I.E. 1990. Thinning lodgepole pine by brute force: three implements in a decade's perspective. For. Chron. 66(6): 611-615. Bella, I.E. and J.P. De Franceschi. 1977. Young lodgepole pine responds to strip thinning, but.... . North. For. Res. Centre, Fisheries and Env. Canada Forestry Serv. Inf. Rep. NOR-X-192. 10 p.

Bella, I.E. and J.P. De Franceschi. 1982. Growth of lodgepole pine after mechanical strip thinning in Alberta: 15-year results. For. Chron. 58(3): 131-135.

Brkich, N. 1981. Fertilizer related density control of lodgepole pine. Progress report, E.P. 789. B.C. Ministry of Forests. Unpublished report.

Brockley, R.P. 1990. Response of thinned, immature lodgepole pine to nitrogen and boron fertilization. Can. J. For. Res. 20(5): 579-585. Cochran, P.H. 1989. Growth rates after fertilizing lodgepole pine. W. J. Appl. For. 4: 18-20.

Cole, D.M. 1993. Problems in lodgepole pine thinnings: basal live limbs and fill-in regeneration. USDA Forest Service, Intermountain Res. Stn. Res. Paper INT-466. 6 p.

Crossley, D.I. 1950. Chemical thinning of young stagnating lodgepole pine stands. Dept. of Resources and Development, For. Res. Div., Canada. Silv. Leaflet No. 42.17 p.

Crossley, D.I. 1952. Discing in overdense lodgepole pine reproduction. Dept. of Resources and Development, For. Res. Div., Canada. Silv. Leaflet No. 66. 3 p.

Crossley, D.I. 1956. The chemical control of density in young stagnating stands of lodgepole pine. For. Res. Div., Dept. of Northern Affairs and Nat. Resources, Canada. Tech. Note 39.

Dahms, W.G. 1971. Fifty-five-year-old lodgepole pine responds to thinning. USDA For. Serv., Pacific NW For. And Range Exp. Stn. Res. Note PNW-141. 13 p.

Dahms, W.G. 1973. Tree growth and water use response to thinning in a 47-year-old lodgepole pine stand. USDA For. Serv., Pacific NW For. And Range Exp. Stn. Res. Note PNW-194. 14 p.

Delong, C., D. Tanner and M.J. Jull. 1993. A field guide for site identification and interpretation for the southwest portion of the Prince George Forest Region. Land management handbook 24. B.C. Ministry of Forests, Victoria.

Forrester, P.D. 1989. Strip thinning with the track-ax in the east Kootenay region of British Columbia. Forest Engineering Research Council of Canada. Tech. Note TN-130. 5 p.

Glen, L. 1979. Tsus and Grove experimental spacing project. Progress report, E.P. 789.02. B.C. Ministry of Forests. Unpublished report.

Goudie, J.W. 1980. The effects of density on the growth and development of repressed lodgepole pine and suppressed inland Douglasfir. Final contract report on EP 850.02. BC Ministry of Forests, Res. Br., Victoria.

Hedin, I.B. 1986. Lodgepole pine stand descriptions for strip thinning machine development. Forest Engineering Research Council of Canada. Tech. Note TN-89. 4 p.

Herring, L.J. and G.M. Cassar-Torreggiani. 1980a. Fertilization and juvenile spacing in stagnant lodgepole pine. Working plan and establishment report, E.P. 789.04. B.C. Ministry of Forests. Unpublished report.
Herring, L.J. and G.M. Cassar-Torreggiani. 1980b. Fertilization related density control in stagnant lodgepole pine. Working plan and establishment report, E.P. 789.03. B.C. Ministry of Forests. Unpublished report.

J.S. Thrower and Assoc. 1993. Paired-plot sampling for height growth repression and recovery in three older juvenile spacing projects in fire-origin lodgepole pine. Contract report to Silv. Branch, B.B Ministry of Forests, Victoria.

Johnstone, W.D. 1981a. Effects of spacing 7-year-old lodgepole pine in west-central Alberta. Canadian Forest Service, Northern For. Res. Cent. Inf. Rep. NOR-X-236. 18 p.

Johnstone, W.D. 1981b. Precommercial thinning speeds growth and development of lodgepole pine: 25 -year results. Canadian Forest Service, Northern For. Res. Cent. Inf. Rep. NOR-X-237. 26 p.

Johnstone, W.D. 1982. Juvenile spacing of 25-year-old lodgepole pine in western Alberta. Canadian Forestry Service, Northern Forestry Centre. Inf. Rep. NOR-X-244.

Keane, M.G. and G.F. Weetman. 1987. Leaf area - sapwood cross-sectional area relationship in repressed stands of lodgepole pine. Can. J. For. Res. 17: 205-209.

Lotan, J.E. 1967. Eleven-year results of strip-thinning by bulldozer in thirty-year-old lodgepole pine. USDA For. Serv., Intermtn. For. \& Range Exp. Stn., Ogden Utah. Res. Note. INT-69.6 p.

Marshall, V.G., H.J. Barclay and E.D. Hetherington. 1992. Lodgepole pine response to nitrogenous fertilizers applied on and off snow, and to associated damage by small mammals. For. Ecol. And Man. 54: 225-238.

Mitchell, K.J. and J.W. Goudie. 1980. Stagnant lodgepole pine. Progress report on EP 850.02, BC Ministry of Forests, Victoria.

Nigh, G.D. 1995. Growth intercept models and tables for British Columbia - interior species. Land Management Handbook Field Guide Insert 10. B.C. Ministry of Forests Research Branch, Victoria.

Reynolds, G. 1989. Climatic data summaries for the biogeoclimatic zones of British Columbia. BC Min. For., Res. Br., Victoria. Unpublished Report.

Schmidt, W.C. 1987. Silvicultural options for small-stem lodgepole pine. In R.L. Barger (Compiler). Management of small-stem stands of lodgepole pine. Workshop Proceedings, Fairmont Hot Springs MT, June 30-July 2 1986. pp. 15-19. USDA Forest Service Intermountain Res. Stn. Gen Tech. Rep. INT-237.

Smithers, L.A. 1957. Thinning in lodgepole pine stands in Alberta. For. Res. Div., Dept. of Northern Affairs and Nat. Resources, Canada. Tech. Note 52.

Sullivan, T.P. 1999. Incremental silviculture of lodgepole pine: integration of stand productivity and non-timber values. Annual Report to For. Renewal BC and Science Council of BC. 25 p.

Tackle, D. and R.C. Shearer. 1959. Strip thinning by bulldozer in a young lodgepole pine stand. Mont. Acad. Of Sci. Proc. 19: 142-148.

Weimer, R.C. 1993. Statistics. 2nd Edition. Wm. C. Brown Publishers, Dubuque Iowa.

Winer, B.J. 1971. Statistical principles in experimental design. 2nd Edition. McGraw-Hill, New York.

Worrall, J. 1995. Height growth stagnation in lodgepole pine: all (well almost all) is revealed. Branchlines 6(3): 5 .

Worrall, J., D.A. Draper and S.A. Anderson. 1985. Shoot characteristics of stagnant and vigorous lodgepole pines, and their growth after reciprocal grafting. Can J. For. Res. 15: 365-370. 